\title{
Timing of Renal Replacement Therapy Initiation in Patients with Septic Acute Kidney Injury; A Systematic Review and Meta-Analysis
}

\section{Hyung Jung Oh}

Sheikh Khalifa Specialty Hospital

In Kyung Min

Yonsei University College of Medicine

Yun Ho Roh

Yonsei University College of Medicine

Jung ho Kim

Yonsei University College of Medicine

Jin Young Ahn

Yonsei University College of Medicine

\section{Su Jin Jeong}

Yonsei University College of Medicine

Jun Yong Choi

Yonsei University College of Medicine

Joon-Sup Yeom

Yonsei University College of Medicine

Young Goo Song

Yonsei University College of Medicine

Nam Su Ku ( $\sim$ smileboy9@yuhs.ac)

Yonsei University College of Medicine https://orcid.org/0000-0002-9717-4327

\section{Yong Eun Chung}

Yonsei University College of Medicine

\section{Research}

Keywords: Timing, RRT, Septic AKI, CRRT

Posted Date: October 29th, 2021

DOI: https://doi.org/10.21203/rs.3.rs-966692/v1

License: (a) This work is licensed under a Creative Commons Attribution 4.0 International License. Read Full License 


\section{Abstract}

Background; Acute kidney injury (AKI) is the most frequent complication seen in patients with septic shock and is an independent risk factor for death. Although renal-replacement therapy (RRT) is standard care for patients with severe septic $\mathrm{AKI}$, the optimal timing of RRT initiation remains controversial.

Methods; The PubMed, Cochrane, and Embase databases were searched from their inception to June 2021 to identify the ideal timing of RRT initiation in patients with septic AKI by comparing 28- and 90-day mortality rates.

Results; Among a total of six studies including 1,058 patients, the 28-day mortality rate was significantly lower in the early RRT-treated group compared to the late group [RR=0.69; $95 \% \mathrm{Cl}(0.51-0.94) ; \mathrm{P}=0.018]$. Moreover, among the five studies including 938 patients, the 90-day mortality rate was also significantly lower in the early RRT-treated group than the late group [RR=0.61; $95 \% \mathrm{Cl}(0.47-0.80) ; \mathrm{P}=0.01]$. In a subgroup analysis for continuous RRT (CRRT), we also found significantly lower 28- and 90-day mortality rates in the early CRRT-treated group compared to the late group.

Conclusion; This study showed that early initiation of RRT might reduce 28- and 90-day mortality compared with late initiation in septic AKI patients.

\section{Introduction}

Acute kidney injury (AKI) is a frequent complication among patients in the intensive care unit (ICU) with septic shock[1-3], because the kidney is one of the first organs to sustain damage with AKI occurring in $51 \%$ of septic shock patients. Meanwhile, the mortality due to septic AKI remain substantial, despite the consistent efforts and advanced developments of medical technology[4]. Currently, septic AKI is associated with more severe hemodynamic instability, greater requirement of mechanical ventilation, longer hospital stay and higher hospital mortality compared with non-septic AKI[4, 5].

Renal replacement therapy (RRT) is a well-known treatment for AKI and benefits patients by controlling fluid balance and correcting acid-base and electrolyte imbalance[6-8]. However, the mortality rate among AKI patients with sepsis, still remains extremely high in spite of RRT treatment[4-9].

Recently, several studies have tried to identify the optimal timing of RRT initiation in critically ill patients[10-12], as there is no consensus on when to begin RRT. Moreover, there are even fewer studies on RRT initiation in septic AKI patients[13-18].

Therefore, we conducted a meta-analysis study by collecting the results of recently published trials in order to explore whether the early initiation of RRT decreases the mortality of septic AKI patients.

\section{Materials And Methods}

This study was conducted and reported according to the Preferred Reporting Items for Systematic Reviews and Metaanalyses (PRISMA) guidelines[19] (Supplemental table 1).

\section{Search strategy}

We performed a comprehensive search of PubMed, EMBASE, the Cochrane Central Registry of Controlled Trials, and Web of Science from the inception of each database to June 2021 to identify randomized trials and cohort studies that assessed when RRT was initiated in septic patients with AKI. We restricted our search to clinical studies performed in adult populations and those that were published in the English language. Twelve keywords, which were "acute renal failure," "acute kidney injury," "acute kidney failure," "continuous renal replacement therapy," "renal replacement therapy," "dialysis," "renal dialysis," "hemofiltration," "sepsis," "septic shock," "time to treatment," and "time factors" were used in the search. The 
bibliographies of the obtained publications and the references of relevant reviews were also checked to ensure that no relevant studies were inadvertently omitted.

\section{Study selection}

Two reviewers ( $\mathrm{HO}$ and NK) independently performed an initial eligibility screen of all retrieved titles and abstracts. Studies that reported original data that specifically mentioned applying RRT in septic patients with AKI were selected for further review. Full-text reviews were independently performed by the same two reviewers with the following eligibility criteria: 1 ) observational cohort and/or randomized clinical trial (RCT) design; 2) adult septic patients; 3 ) diagnosis of AKI; 4) description of factors related to the timing of RRT initiation; and 5) description of mortality outcomes. Any discrepancies were resolved in a consensus discussion mediated by a third reviewer (YC). Our study's protocol was registered in PROSPERO. The authors did not seek specific institutional review board or ethics committee approval for this study because the study was conducted with publicly available data obtained from online databases.

\section{Assessment of risk of bias}

The quality of the included RCTs was assessed using the Cochrane Collaboration Risk of Bias Tool[20](Supplemental table 2). The quality of the observational studies was evaluated using the Newcastle-Ottawa Scale (NOS)[21] (Supplemental table 3). Studies with NOS scores $<7$ were considered to have high risks of bias[22, 23].

\section{Data extraction and statistical analysis}

The author, publication year, study type, study location, RRT modality, RRT timing and mortality outcomes were extracted from each of the included studies. In addition, we contacted the authors of these studies for missing or incomplete data. The primary outcome was the 28-day mortality of patients in whom RRT was initiated. The 90-day mortality was the secondary outcome. A meta-analysis was performed using the package 'meta' and 'metafor' of the R package, version 3.6.0 (The R Foundation for Statistical Computing, Vienna, Austria). Pooled estimates of risk ratios (RRs) with $95 \%$ confidence intervals (Cls) were calculated using random effects models based on the restricted maximum-likelihood estimator of the between-study variance to take account for heterogeneity among studies. An additional subgroup analysis of CRRT and the impact of its initiation time on 28- and 90-day mortality was performed with the same protocol. Significant statistical heterogeneity was determined by the $\mathrm{Q}$-statistic test $(\mathrm{P}<.10)$ and $\mathrm{I}$-squared statistics $(\mathrm{I} 2 \geq 50 \%)$. A $\mathrm{P}$ value $<.05$ was set as the threshold of statistical significance. Publication bias was assessed using Egger's regression model, and visualized with a contour-enhanced funnel plot. Additionally, the trim and fill method was performed to investigate potential effects due to unpublished studies.

\section{Results}

\section{Study selection and quality assessment}

We initially collected 5,566 articles from the three medical databases. After removing the duplicate articles, 4,478 remained. $\mathrm{HO}$ and NK then screened the titles and abstracts of the articles and deleted 4,439 irrelevant studies. Then, 39 articles underwent full-text assessment. Thirty-three articles were excluded as 12 were review or case studies and 21 were either conference papers, not written in English, or not full-text papers. Therefore, only 6 articles were chosen for the final analysis (Table 1 and Figure 1). Of the 6 articles, one was a RCT[14] and five were retrospective cohort studies[13, 15-18]. The results of our quality assessment are shown in Supplemental Table 1 and Supplemental Table 2. The RCT did not have a high risk of bias for sequence generation, addressing outcome data, selective reporting, or funding source. All of the retrospective studies had total bias scores of at least 7 based on NOS, which indicates a low risk of bias. 
Table 1

The basic characteristics of studies included in meta-analysis

\begin{tabular}{|c|c|c|c|c|c|c|c|c|c|}
\hline \multirow[t]{2}{*}{ Author } & \multirow[t]{2}{*}{ Year } & \multirow[t]{2}{*}{ Country } & \multirow[t]{2}{*}{$\begin{array}{l}\text { Study } \\
\text { period }\end{array}$} & \multirow[t]{2}{*}{ Study design } & \multirow[t]{2}{*}{ Modality } & \multicolumn{2}{|c|}{$\begin{array}{l}\text { No. of } \\
\text { patients }\end{array}$} & \multirow[t]{2}{*}{ Early criteria } & \multirow[t]{2}{*}{ Late criteria } \\
\hline & & & & & & Early & Late & & \\
\hline Chon $^{19}$ & 2012 & Korea & $\begin{array}{l}2009- \\
2010\end{array}$ & $\begin{array}{l}\text { Retrospective } \\
\text { cohort }\end{array}$ & CRRT & 36 & 19 & $\begin{array}{l}\text { Time from } \\
\text { sepsis to } \\
\text { inception of } \\
\text { CRRT } \leq 24 \mathrm{~h}\end{array}$ & $\begin{array}{l}\text { Time from } \\
\text { sepsis to } \\
\text { inception of } \\
\text { CRRT }>24 \mathrm{~h}\end{array}$ \\
\hline Shum $^{18}$ & 2013 & China & $\begin{array}{l}2008- \\
2011\end{array}$ & $\begin{array}{l}\text { Retrospective } \\
\text { cohort }\end{array}$ & CRRT & 31 & 89 & $\begin{array}{l}\text { Simplified } \\
\text { RIFLE risk, } \\
\text { GFR } \\
\text { decrease } \\
>25 \% \text { from } \\
\text { baseline }\end{array}$ & $\begin{array}{l}\text { Simplified } \\
\text { RIFLE Injury or } \\
\text { Failure, GFR } \\
\text { decrease } \\
>50 \% \text { from } \\
\text { baseline }\end{array}$ \\
\hline $\mathrm{Oh}^{17}$ & 2016 & Korea & $\begin{array}{l}2008- \\
2013\end{array}$ & $\begin{array}{l}\text { Retrospective } \\
\text { cohort }\end{array}$ & CRRT & 30 & 30 & $\begin{array}{l}\text { Interval } \\
\text { between the } \\
\text { start of } \\
\text { EGDT and } \\
\text { CRRT } \\
\text { initiation } \\
\leq 26.4 \mathrm{~h}\end{array}$ & $\begin{array}{l}\text { Interval } \\
\text { between the } \\
\text { start of EGDT } \\
\text { and CRRT } \\
\text { initiation } \\
>26.4 \mathrm{~h}\end{array}$ \\
\hline Baek $^{16}$ & 2017 & Korea & $\begin{array}{l}2014- \\
2015\end{array}$ & $\begin{array}{l}\text { Retrospective } \\
\text { cohort }\end{array}$ & CRRT & 125 & 52 & $\begin{array}{l}\text { The time } \\
\text { from the } \\
\text { start of } \\
\text { vasopressor } \\
\text { infusion to } \\
\text { the initiation } \\
\text { of CRRT } \leq 24 \\
\text { h }\end{array}$ & $\begin{array}{l}\text { The time from } \\
\text { the start of } \\
\text { vasopressor } \\
\text { infusion to the } \\
\text { initiation of } \\
\text { CRRT }>24 \mathrm{~h}\end{array}$ \\
\hline Barber $^{15}$ & 2018 & France & $\begin{array}{l}2012- \\
2016\end{array}$ & $\begin{array}{l}\text { Prospective, } \\
\text { randomized } \\
\text { controlled } \\
\text { trial }\end{array}$ & RRT/CRRT & 246 & 242 & $\begin{array}{l}\text { Renal- } \\
\text { replacement } \\
\text { therapy was } \\
\text { started } \\
\text { within } 12 \mathrm{~h} \\
\text { after the } \\
\text { onset of } \\
\text { acute kidney } \\
\text { injury that } \\
\text { was } \\
\text { determined } \\
\text { to be at the } \\
\text { failure stage } \\
\text { of RIFLE } \\
\text { classification }\end{array}$ & $\begin{array}{l}\text { Renal- } \\
\text { replacement } \\
\text { therapy was } \\
\text { initiated after } \\
\text { a delay of } 48 \\
\text { h if renal } \\
\text { function did } \\
\text { not } \\
\text { spontaneously } \\
\text { recover and if } \\
\text { no condition } \\
\text { meeting the } \\
\text { criteria for } \\
\text { emergency } \\
\text { renal- } \\
\text { replacement } \\
\text { therapy } \\
\text { developed }\end{array}$ \\
\hline Yoon $^{14}$ & 2020 & Korea & $\begin{array}{l}2016- \\
2018\end{array}$ & $\begin{array}{l}\text { Retrospective } \\
\text { cohort }\end{array}$ & CRRT & 93 & 65 & $\begin{array}{l}\text { the interval } \\
\text { time from } \\
\text { AKI to CRRT } \\
\text { initiation } \\
\text { using the } \\
\text { cut-of time } \\
\text { by the } \\
\text { AUROC } \\
\text { curve }<16.5 \mathrm{~h}\end{array}$ & $\begin{array}{l}\text { the interval } \\
\text { time from AKI } \\
\text { to CRRT } \\
\text { initiation } \\
\text { using the cut- } \\
\text { of time by the } \\
\text { AUROC } \\
\text { curve } \geq 16.5 \mathrm{~h}\end{array}$ \\
\hline $\begin{array}{l}\text { Abbreviat } \\
\text { kidney dis } \\
\text { operating }\end{array}$ & $\begin{array}{l}\mathrm{ns} ; \mathrm{No} \\
\text { ase; Gi } \\
\text { naract }\end{array}$ & $\begin{array}{l}\text { umber; C } \\
\text { glomeru } \\
\text { stic }\end{array}$ & $\begin{array}{l}\text { TT, conti } \\
\text { filtratic }\end{array}$ & $\begin{array}{l}\text { ous renal repla } \\
\text { rate; EGDT, ear }\end{array}$ & $\begin{array}{l}\text { ement thera } \\
\text { goal directe }\end{array}$ & $\begin{array}{l}\text {; RIFLE } \\
\text { therap }\end{array}$ & $\begin{array}{l}\text { isk, in } \\
\text { AURO }\end{array}$ & $\begin{array}{l}\text { ry, failure, loss } \\
\text { area under th }\end{array}$ & $\begin{array}{l}\text { nd end-stage } \\
\text { eceiver }\end{array}$ \\
\hline
\end{tabular}




\section{Study characteristics}

There were 6 studies with a total of 1,058 patients included in our meta-analysis. Five studies were retrospective cohort studies conducted in a single center, and one was a randomized-controlled multi-center study. Four studies were performed in Korea, one in China, and another in France. In addition, we presented the different definitions of early and late RRT initiation used in each study in Table 1. Five studies explored how the timing of RRT initiation impacted 28- and 90-day mortality, whereas one study only investigated the impact of timing on 28-day mortality.

\section{The effect of early RRT on 28-day mortality}

Among a total of 6 studies including 1,058 patients, the 28-day mortality rate of patients with septic AKI was $44.5 \%$ [222/561 (39.6\%) in the early RRT-treated group and 249/497 (50.1\%) in the late group]. As a result of pooling risk ratios of 6 studies, the 28-day mortality rate was significantly lower in the early RRT-treated group compared with that in the late group [RR=0.69; 95\% $\mathrm{Cl}(0.51-0.94) ; \mathrm{P}=0.018]$ with wild heterogeneity $(\mathrm{Q}=23.31, \mathrm{P}<0.01)$ (Figure 2).

\section{The effect of early RRT on 90-day mortality}

Next, we compared 90-day mortality rates among 5 studies (with the study of Shum et al. being excluded) with a total of 938 patients, and the 90 -day mortality rate was $56.5 \%$ [272/530 (51.3\%) in the early RTT-treated group and 258/408 (63.2\%) in the late group]. Moreover, the 90-day mortality rate was also significantly lower in the early RRT-treated group than in the late group [RR=0.61;95\% $\mathrm{Cl}(0.47-0.80) ; \mathrm{P}=0.01$ ] with wild heterogeneity $(\mathrm{Q}=27.41, \mathrm{P}<0.01)$ (Figure 3$)$.

\section{The effect of early CRRT on mortality}

Among the six studies, only one included patients undergoing intermittent hemodialysis. However, we explored the impact of early CRRT initiation on 28- and 90-day mortality, and compared 28-day mortality between the early and late groups with 5 studies and 90-day mortality with 4 studies (excluding the study of Shum et al.).

The 28-day mortality was $45.3 \%$ [111/315 (35.2\%) in the early CRRT-treated group and $147 / 255$ (57.6\%) in the late group], while the 90 -day mortality was $56.9 \%$ [129/284 (45.4\%) in the early group and $127 / 166(76.5 \%)$ in the late group]. Moreover, Figure 4 and 5 showed that the 28- and 90-day mortality rates were also significantly lower in the early CRRT-treated group than the late group [for 28-day mortality; $R R=0.61 ; 95 \% \mathrm{Cl}(0.47-0.80) ; \mathrm{P}<0.001$ with wild heterogeneity $(\mathrm{Q}=6.97, \mathrm{P}=0.14)$, for 90-day mortality; $R R=0.60 ; 95 \% \mathrm{Cl}(0.51-0.70) ; \mathrm{P}<0.001]$ with wild heterogeneity $(\mathrm{Q}=0.11, \mathrm{P}=0.99)$.

\section{Publication bias}

The results of Egger's tests show no significant bias in all studies (for the 28- and 90-day mortality of RRT-treated patients; $\mathrm{P}=0.170$ and $\mathrm{P}=0.318$, respectively, and for the 28- and 90-day mortality of CRRT-treated patients; $\mathrm{P}=0.564$ and $\mathrm{P}=0.784$, respectively) (Figure supplement 1). For 28-day mortality, the one missing study was estimated by the trim and fill method, and the adjusted pooled estimate was still significant after imputing the hypothetical study $[\mathrm{RR}=0.61 ; 95 \% \mathrm{Cl}(0.47-0.80)$; $P=0.01]$. Moreover, our study indicates that evidence quality was low due to the risk of bias, indirectness, and imprecision.

\section{Discussion}

Even though there have been several studies on the benefits of early RRT in critically ill patients, there is still debate on whether those benefits are worth early RRT initiation. Zarbock et al.[24] reported that the 90-day mortality rate of patients who received early RRT was significantly lower than that of patients who initiated RRT later, whereas neither Gaudry et al. [25] nor Bagshaw et al.[26] showed significant differences in mortality rates (28- and 60-day mortality for Gaudry et al. and 90-day mortality for Bagshaw et al.) between early and late RRT initiation. For septic AKI patients, Barbar et al.[14] found no significant difference in 90-day mortality between patients who received early and late RRT. Consistently with the findings of 
Barbar et al., Li et al.[27] also found no significant differences in 28- and 90-day mortality rates according to RRT timing in their meta-analysis on septic AKI patients. Apparently, recent RCTs and meta-analysis did not show early RRT initiation as improving survival rates in critically ill patients with AKI including septic AKI.

However, it does not mean that we need to delay RRT as much as possible. Gaudry et al.[25] stated that their study should not be interpreted as suggesting that a "wait and see" approach is safe for all patients. Indeed, careful surveillance is mandatory when deciding to delay RRT in patients with severe AKI so that RRT can be initiated as soon as any complications are detected. Rather, the issue is how to identify a reasonable time point for beginning treatment. Moreover, Barbar et al.[14] demonstrated that the failure stage was not necessarily intended to identify patients who would require RRT, and a delay of only 48 hours may not be sufficiently long enough to allow renal function to recover in some patients or to cause a difference between early and late RRT initiation.

We realized that each study used different definitions to describe early and late RRT[14, 24-26]. Unlikely RCTs, most of the retrospective cohort studies showed that early initiation of RRT decreased mortality compared with delayed initiation[13, 15 , 17, 18]. But all the patients included in this study were those who underwent RRT. Hence, the early RRT-treated group might have included several patients who would not need RRT if followed with close observation, and that might explain the better prognosis of the early group. Meanwhile, both Gaudry[25] and Barbar et al.[14] recognized that quite a few patients did not undergo RRT in the late group, with their renal functions spontaneously resolving. Barbar et al.[14] pointed out that 70 patients among the total of 242 patients in the late group (28.9\%) did not receive RRT, which means "delay of RRT" in these studies might not be a true "delay" in practical condition, suggesting that could be one of the limitations in the Barbar's study.

With the earlier initiation of dialysis in AKI, we expect to improve acid-base, electrolyte, and fluid balance, and thereby prevent more aggravating complications of $\mathrm{AKI}$ and perhaps also enhance the removal of toxins such as nonspecific proinflammatory or anti-inflammatory mediators through convection and adsorption[28]. Moreover, fluid therapy and usage of other drugs may be easily done through the fluid management of RRT[28]. These points suggest that RRT may be initiated without delay, when deemed necessary.

The strength of this meta-analysis was that it was conducted with only septic AKI patients that underwent RRT as well as CRRT, and we searched for all the related papers published until June of 2021. Several limitations still need to be discussed. First, small-sized studies were included. Most of the studies on RRT timing were for critically ill patients, not septic AKI patients. Only a few studies included septic AKI patients. Second, substantial heterogeneity was shown even in the few studies, which suggests that the findings of the current study should be interpreted with caution.

\section{Conclusions}

In conclusion, this study found that early initiation of RRT and CRRT might reduce 28- and 90-day mortality compared to late initiation in septic AKI patients. However, continuous studies are required with different criteria to identify the optimal timing of RRT and CRRT in septic AKI patients in the future.

\section{Abbreviations}

AKI

Acute kidney injury

RRT

renal-replacement therapy

CRRT

continuous renal-replacement therapy

RCT 
randomized clinical trial

Cls

confidence intervals

\section{Declarations}

\section{Authors' contributions}

HJO, JHK, JYA, SJJ, JYC, JSY, YGS, NSK, and YEC have made substantial contributions to the conception and design of this study. HJO, IKM, RYH, NSK, and YEC have made contributions to the acquisition and interpretation of the data. IKM and RYH have made contributions to the statistical analysis. HJO, NSK, and YEC drafted the article and revised it for important intellectual content. All the authors took part in the manuscript writing and approved the final manuscript.

\section{Funding}

This research was not supported by any grant.

\section{Availability of data and materials}

The data that support the findings of this study are available from the corresponding authors upon reasonable request.

\section{Ethics approval and consent to participate}

This study did not seek specific institutional review board or ethics committee approval because the study was conducted with publicly available data obtained from online database

\section{Consent for publication}

We obtained consent to publish from the participants for the reporting of individual patient data.

\section{Competing interests}

The authors declare that they have no competing interests.

\section{References}

1. Hoste EA, Bagshaw SM, Bellomo R, Cely CM, Colman R, Cruz DN, Edipidis K, Forni LG, Gomersall CD, Govil D, et al. Epidemiology of acute kidney injury in critically ill patients: the multinational AKI-EPI study. Intensive Care Med. 2015;41(8):1411-23.

2. Mehta RL, Cerda J, Burdmann EA, Tonelli M, Garcia-Garcia G, Jha V, Susantitaphong P, Rocco M, Vanholder R, Sever MS, et al. International Society of Nephrology's 0by25 initiative for acute kidney injury (zero preventable deaths by 2025): a human rights case for nephrology. Lancet. 2015;385(9987):2616-43.

3. Quenot JP, Binquet C, Kara F, Martinet O, Ganster F, Navellou JC, Castelain V, Barraud D, Cousson J, Louis G, et al. The epidemiology of septic shock in French intensive care units: the prospective multicenter cohort EPISS study. Crit Care. 2013;17(2):R65.

4. Bagshaw SM, Uchino S, Bellomo R, Morimatsu H, Morgera S, Schetz M, Tan I, Bouman C, Macedo E, Gibney N, et al. Septic acute kidney injury in critically ill patients: clinical characteristics and outcomes. Clin J Am Soc Nephrol. 2007;2(3):431-9.

5. Bellomo R, Kellum JA, Ronco C, Wald R, Martensson J, Maiden M, Bagshaw SM, Glassford NJ, Lankadeva Y, Vaara ST, et al. Acute kidney injury in sepsis. Intensive Care Med. 2017;43(6):816-28. 
6. Tolwani A. Continuous renal-replacement therapy for acute kidney injury. N Engl J Med. 2012;367(26):2505-14.

7. Uchino S, Kellum JA, Bellomo R, Doig GS, Morimatsu H, Morgera S, Schetz M, Tan I, Bouman C, Macedo E, et al. Acute renal failure in critically ill patients: a multinational, multicenter study. JAMA. 2005;294(7):813-8.

8. Kellum JA, Mehta RL, Levin A, Molitoris BA, Warnock DG, Shah SV, Joannidis M, Ronco C, Acute Kidney Injury N. Development of a clinical research agenda for acute kidney injury using an international, interdisciplinary, three-step modified Delphi process. Clin J Am Soc Nephrol. 2008;3(3):887-94.

9. Cerda J, Liu KD, Cruz DN, Jaber BL, Koyner JL, Heung M, Okusa MD, Faubel S. Nephrology AKIAGotASo: Promoting Kidney Function Recovery in Patients with AKI Requiring RRT. Clin J Am Soc Nephrol. 2015;10(10):1859-67.

10. Seabra VF, Balk EM, Liangos O, Sosa MA, Cendoroglo M, Jaber BL. Timing of renal replacement therapy initiation in acute renal failure: a meta-analysis. Am J Kidney Dis. 2008;52(2):272-84.

11. Karvellas CJ, Farhat MR, Sajjad I, Mogensen SS, Leung AA, Wald R, Bagshaw SM. A comparison of early versus late initiation of renal replacement therapy in critically ill patients with acute kidney injury: a systematic review and metaanalysis. Crit Care. 2011;15(1):R72.

12. Bien-Ly N, Yu YJ, Bumbaca D, Elstrott J, Boswell CA, Zhang Y, Luk W, Lu Y, Dennis MS, Weimer RM, et al. Transferrin receptor (TfR) trafficking determines brain uptake of TfR antibody affinity variants. J Exp Med. 2014;211(2):233-44.

13. Yoon BR, Leem AY, Park MS, Kim YS, Chung KS. Optimal timing of initiating continuous renal replacement therapy in septic shock patients with acute kidney injury. Sci Rep. 2019;9(1):11981.

14. Barbar SD, Clere-Jehl R, Bourredjem A, Hernu R, Montini F, Bruyere R, Lebert C, Bohe J, Badie J, Eraldi JP, et al. Timing of Renal-Replacement Therapy in Patients with Acute Kidney Injury and Sepsis. N Engl J Med. 2018;379(15):1431-42.

15. Baek SD, Yu H, Shin S, Park HS, Kim MS, Kim SM, Lee EK, Chang JW. Early continuous renal replacement therapy in septic acute kidney injury could be defined by its initiation within 24 hours of vasopressor infusion. J Crit Care. 2017;39:108-14.

16. Oh HJ, Kim MH, Ahn JY, Ku NS, Park JT, Han SH, Choi JY, Han SH, Yoo TH, Song YG, et al. Can early initiation of continuous renal replacement therapy improve patient survival with septic acute kidney injury when enrolled in early goal-directed therapy? J Crit Care. 2016;35:51-6.

17. Shum HP, Chan KC, Kwan MC, Yeung AW, Cheung EW, Yan WW. Timing for initiation of continuous renal replacement therapy in patients with septic shock and acute kidney injury. Ther Apher Dial. 2013;17(3):305-10.

18. Chon GR, Chang JW, Huh JW, Lim CM, Koh Y, Park SK, Park JS, Hong SB. A comparison of the time from sepsis to inception of continuous renal replacement therapy versus RIFLE criteria in patients with septic acute kidney injury. Shock. 2012;38(1):30-6.

19. Hutton B, Salanti G, Caldwell DM, Chaimani A, Schmid CH, Cameron C, loannidis JP, Straus S, Thorlund K, Jansen JP, et al. The PRISMA extension statement for reporting of systematic reviews incorporating network meta-analyses of health care interventions: checklist and explanations. Ann Intern Med. 2015;162(11):777-84.

20. Higgins JP, Altman DG, Gotzsche PC, Juni P, Moher D, Oxman AD, Savovic J, Schulz KF, Weeks L, Sterne JA, et al. The Cochrane Collaboration's tool for assessing risk of bias in randomised trials. BMJ. 2011;343:d5928.

21. The Newcastle-Ottawa Scale (NOS) for assessing the quality of nonrandomised studies in meta-analyses [http://www.ohri.ca/programs/clinical_epidemiology/oxford.asp].

22. Yang Y, Zhang F, Skrip L, Lei H, Luo S, Lu K, Hu D. Lack of an association between angiotensin receptor blocker based therapy and increased risk of cancer: evidence from large observational studies. PLoS One. 2015;10(3):e0119775.

23. Zhang YP, Wan YD, Sun YL, Li J, Zhu RT. Aspirin might reduce the incidence of pancreatic cancer: A meta-analysis of observational studies. Sci Rep. 2015;5:15460.

24. Zarbock A, Kellum JA, Schmidt C, Van Aken H, Wempe C, Pavenstadt H, Boanta A, Gerss J, Meersch M. Effect of Early vs Delayed Initiation of Renal Replacement Therapy on Mortality in Critically III Patients With Acute Kidney Injury: The ELAIN Randomized Clinical Trial. JAMA. 2016;315(20):2190-9.

Page 8/12 
25. Gaudry S, Hajage D, Schortgen F, Martin-Lefevre L, Pons B, Boulet E, Boyer A, Chevrel G, Lerolle N, Carpentier D, et al. Initiation Strategies for Renal-Replacement Therapy in the Intensive Care Unit. N Engl J Med. 2016;375(2):122-33.

26. Investigators S-A, Canadian Critical Care Trials G, Australian, New Zealand Intensive Care Society Clinical Trials G, United Kingdom Critical Care Research G, Canadian Nephrology Trials N, Irish Critical Care Trials G, Bagshaw SM, Wald R, Adhikari NKJ, et al. Timing of Initiation of Renal-Replacement Therapy in Acute Kidney Injury. N Engl J Med. 2020;383(3):240-51.

27. Li Y, Li H, Zhang D. Timing of continuous renal replacement therapy in patients with septic AKI: A systematic review and meta-analysis. Med (Baltim). 2019;98(33):e16800.

28. Joannidis M, Forni LG. Clinical review: timing of renal replacement therapy. Crit Care. 2011;15(3):223.

\section{Figures}

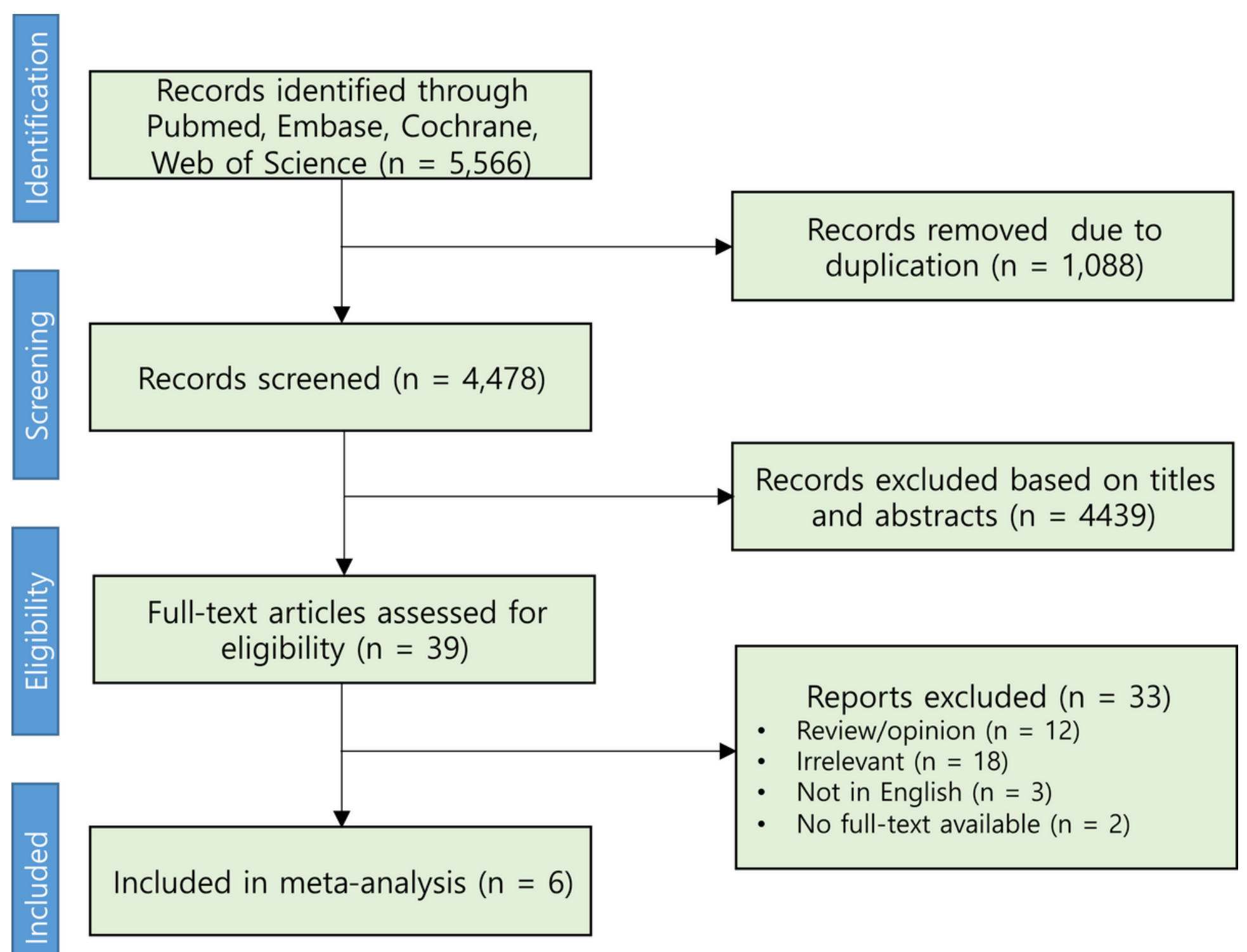

Figure 1

Flow chart of literature selection 


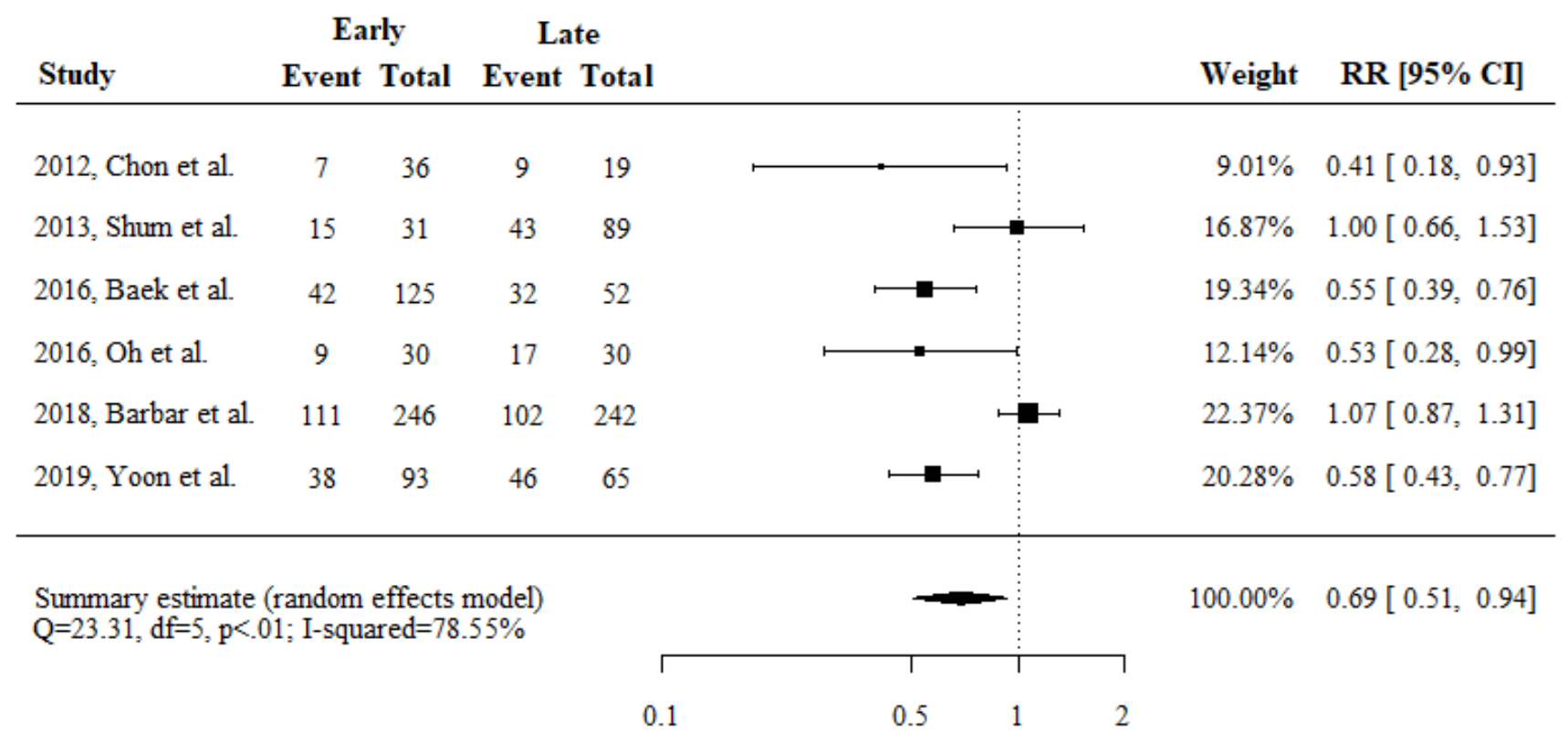

Risk Ratio (RR)

\section{Figure 2}

Meta-analysis of risk ratios for 28-day mortality in the RRT group. Higher risk ratios indicate higher 28-day mortality in the early RRT-treated group. RRT, renal replacement therapy; RR, risk ratio; Cl confidence interval

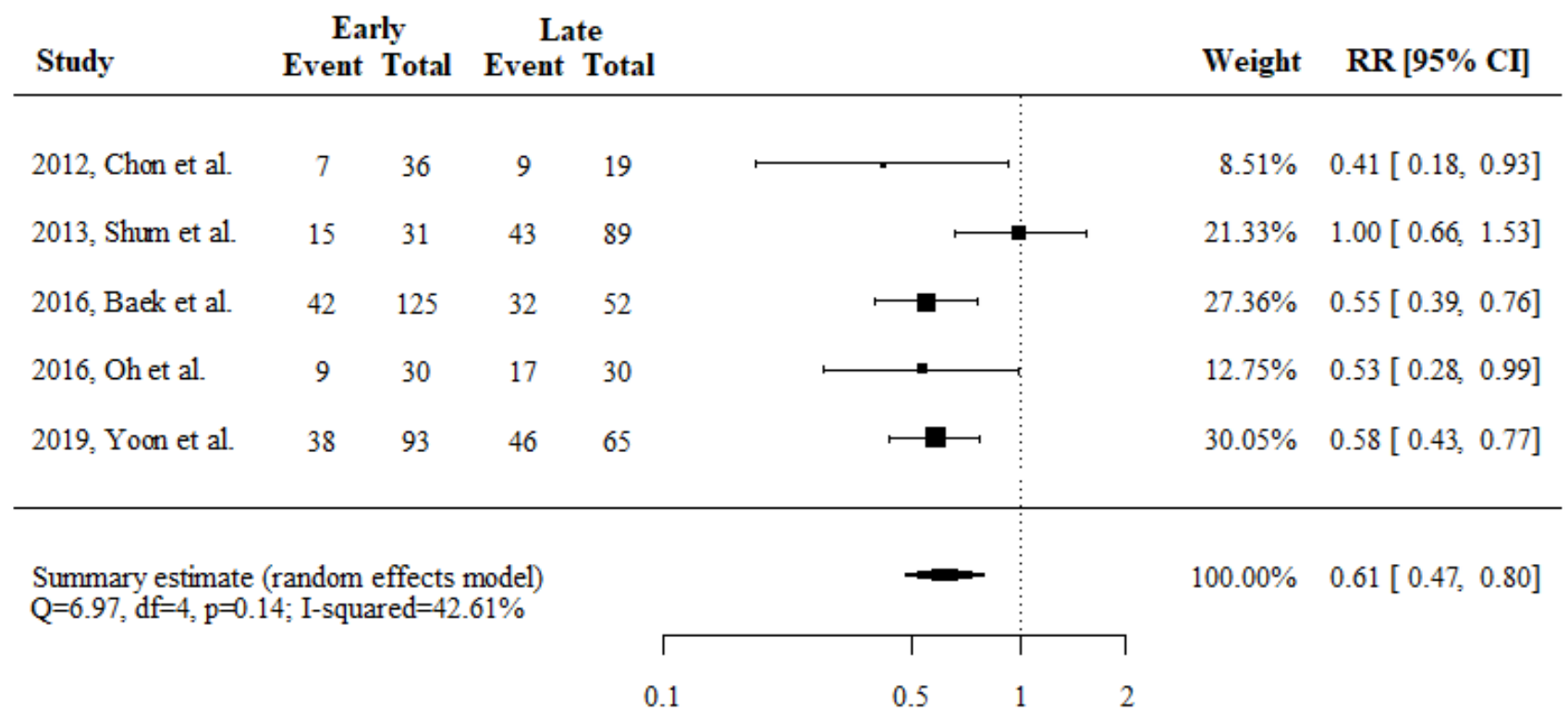

Risk Ratio (RR) 


\section{Figure 3}

Meta-analysis of risk ratios for 90-day mortality in the RRT group. Higher risk ratios indicate higher 90-day mortality in the early RRT-treated group. RRT, renal replacement therapy; RR, risk ratio; Cl confidence interval

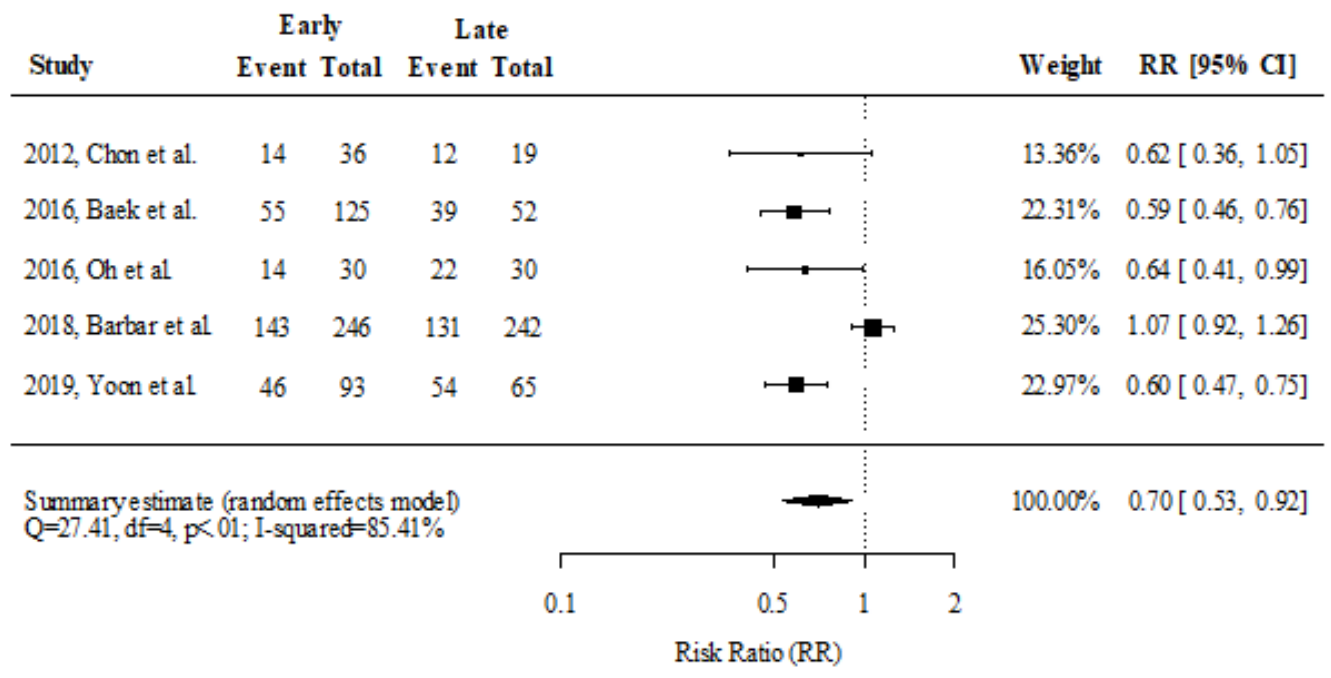

\section{Figure 4}

Meta-analysis of risk ratios for 28-day mortality in the CRRT group. Higher risk ratios indicate higher 28-day mortality in the early CRRT-treated group. CRRT, continuous renal replacement therapy; RR, risk ratio; Cl confidence interval

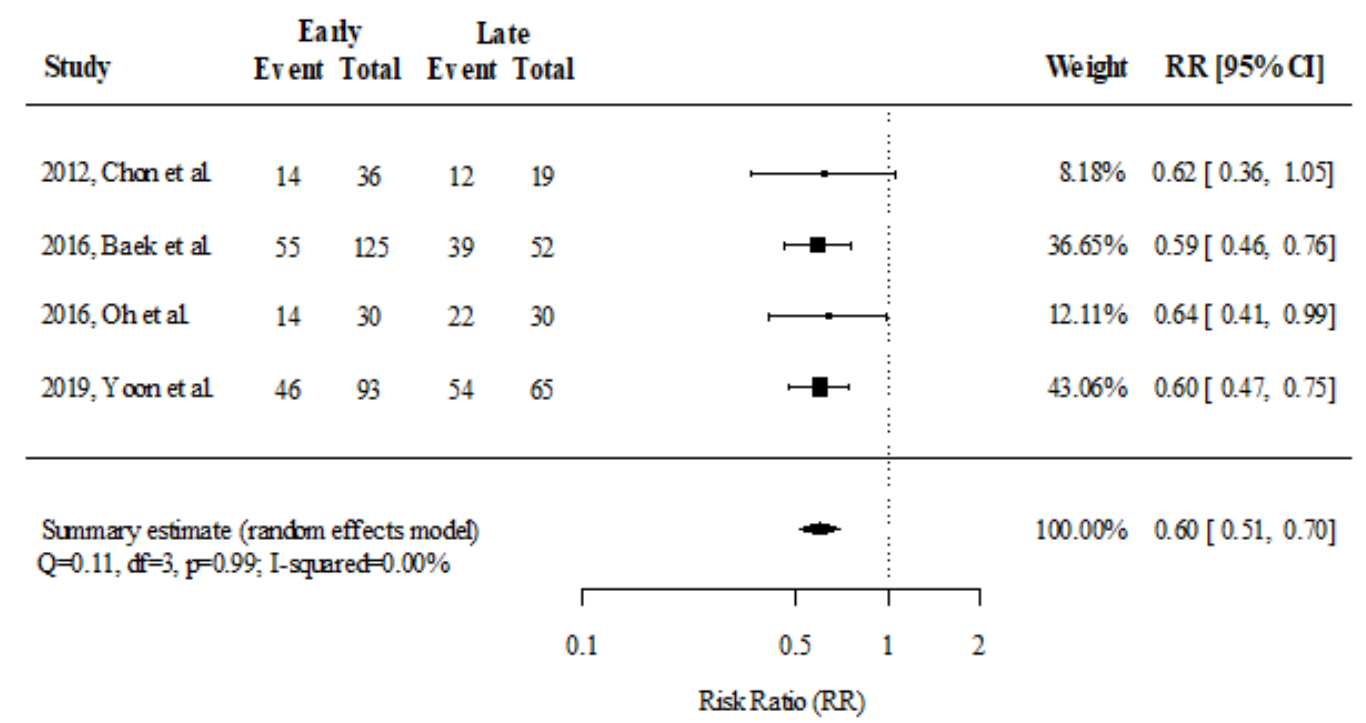

\section{Figure 5}

Meta-analysis of risk ratios for 90-day mortality in the CRRT group. Higher risk ratios indicate higher 90-day mortality in the early CRRT-treated group. CRRT, continuous renal replacement therapy; RR, risk ratio; Cl confidence interval 


\section{Supplementary Files}

This is a list of supplementary files associated with this preprint. Click to download.

- FigureSupplement1.Funnelplots.png

- Supplementaltable1.PRISMAchecklist.docx

- Supplementaltable2.docx

- Supplementaltable3.docx 